\title{
Cardiovascular complications and increased levels of circulating modified low density lipoprotein in HIV patients and patients with lipodystrophy
}

K.R.O.M. Ronchini ${ }^{1}$,

A.J.S. Duarte ${ }^{2}$,

J.S.R. Casseb ${ }^{2}$

and M. Gidlund ${ }^{1,3}$

\section{Correspondence}

M. Gidlund

Laboratório de Imunofisiopatologia

UP10, Departamento de Imunologia

ICB-IV, USP

Av. Prof. Lineu Prestes, 1730

05508-900 São Paulo, SP

Brasil

Fax: +55-11-3091-7224

E-mail: gidlundm@usp.br

Presented at the I Symposium on Advances in Medical Research, Institute of Medical Investigation Laboratories, HC-FMUSP, São Paulo, SP, Brazil, March 21-22, 2003.

Research supported by FAPESP, CNPq, CAPES, LIM-38 and LIM-56.

Received June 16, 2003 Accepted August 27, 2003

\author{
'Laboratório de Imunofisiopatologia, Departamento de Imunologia, \\ Instituto de Ciências Biomédicas, \\ ${ }^{2}$ Laboratório de Alergia e Imunologia Clínica Experimental, LIM-56, and \\ ${ }^{3}$ Laboratório de Soroepidemiologia e Imunobiologia, \\ Instituto de Medicina Tropical de São Paulo e Laboratório de Soroepidemiologia, \\ LIM-38, Hospital das Clínicas, Faculdade de Medicina, \\ Universidade de São Paulo, São Paulo, SP, Brasil
}

\begin{abstract}
The introduction of highly active antiretroviral therapy (HAART) for patients infected with HIV has significantly prolonged the life expectancy and to some extent has restored a functional immune response. However, the premature introduction of HAART has led to a significant and alarming increase in cardiovascular complications, including myocardial infarction and the appearance of abnormal distribution of body fat seen as lipodystrophy. One key element in the development of ischemic coronary artery disease is the presence of circulating and tissue-fixed modified low density lipoprotein (mLDL) that contributes to the initiation and progression of arterial lesions and to the formation of foam cells. Even though not completely elucidated, the most likely mechanism involves mLDL in the inflammatory response and the induction of a specific immune response against mLDL. Circulating antibodies against $\mathrm{mLDL}$ can serve as an indirect marker of the presence of circulating and vessel-fixed mLDL. In the present study, we measured antibodies to $\mathrm{mLDL}$ and correlated them with immune status (i.e., number of $\mathrm{CD} 4^{+} \mathrm{T}$ cells) in $59 \mathrm{HIV}$ patients and with the clinical manifestation of lipodystrophy in 10 patients. We observed a significant reduction in anti-mLDL antibody levels related both to lipodystrophy and to an immunocompromised state in HIV patients. We speculate that these antibodies may explain in part the rapid development of ischemic coronary artery disease in some patients.
\end{abstract}

Key words

- HIV

- Oxidized LDL

- Modified low density

lipoprotein

- Lipodystrophy

- Coronary artery

disease
HIV infection causes a gradual decay of immune function and the subsequent opportunistic infections are the major cause of death in these patients. However, the early introduction of potent inhibitors of viral rep- lication commonly used for therapy in various combinations known as highly active antiretroviral therapy (HAART), already at phase II of clinical trials, has significantly prolonged the life expectancy of patients 
with HIV infection. Conversely, during recent years, a significant and alarming increase in cardiovascular complications, including myocardial infarctions, have been noted in these patients. In addition, the appearance of abnormal distribution of body fat seen as lipodystrophy can be considered to be a recent and increasing event in patients undergoing HAART. These side effects may directly or indirectly be related to infection or to the metabolic alterations imposed by the drugs (for additional references, see Ref. 1). Lipid alterations such as an increase in triglycerides and a decrease in high density lipoprotein and low density lipoprotein (LDL)-cholesterol have been reported in these patients $(1,2)$.

In many pathological processes several LDL modifications may occur, including methylation, acetylation and, most commonly, those generated by oxidative stress. The oxidatively induced modifications in conjunction with subsequent secondary modifications (e.g., enzymatic) result in a completely degraded LDL particle (reviewed in Refs. 3,4). These fragments have been shown to be biologically active and their effects range from induction of apoptosis and production of cytokine vasoactive properties to stimulation and induction of an immune response (5-9). The presence of modified LDL (mLDL) is associated with several disease conditions (e.g. atherosclerosis, rheumatoid arthritis) as well as conditions that may favor the development of ischemic coronary artery disease (CAD) (6$8,10)$. Some investigators, including our group, have recently suggested that there are at least two functional classes of antibodies against mLDL: those that can directly or indirectly induce and propagate the disease and those that can be protective by virtue of removal or neutralization of potentially hazardous mLDL (11-14, and Fernvik E and Gidlund M, unpublished results). In addition, the presence of low levels of antibodies is related to the presence of increased levels of mLDL both circulating and fixed to the arterial wall $(11,12,15,16)$.

The clinical profiles of HIV patients have dramatically changed during recent years, now including not only opportunistic infections but also type II diabetes, CAD, and lipodystrophy $(1,2)$. Since the presence of $\mathrm{mLDL}$ and antibodies against $\mathrm{mLDL}$ is considered to be a risk factor for cardiovascular complications, in the present report we investigated the presence of plasma antibodies against mLDL in 59 HIV patients.

Written informed consent was obtained from the patients and the project was approved by the Hospital Ethics Committee. HIV infects and kills $\mathrm{CD} 4^{+} \mathrm{T}$ cell that are the key cell in the development of a humoral immune response. We therefore tested plasma samples from 59 HIV patients divided according to their $\mathrm{CD}^{+} \mathrm{T}$ cell counts in peripheral blood, determined by routine flow cytometry carried out at Hospital das Clínicas: patients with normal $\mathrm{CD}^{+} \mathrm{T}$ cell counts $>450$ cells $/ \mathrm{mm}^{3}(\mathrm{~N}=80$ samples from 22 patients) and patients with $\mathrm{CD} 4^{+} \mathrm{T}$ cell counts $<450$ cells $/ \mathrm{mm}^{3}(\mathrm{~N}=110$ samples from 37 patients).

The presence of anti-mLDL IgG antibodies was determined by our standardized ELISA using oxidized LDL and patient plasma samples $(11,17)$. Briefly, LDL obtained by sequential ultracentrifugation was submitted to copper-oxidation $(20 \mu \mathrm{M}$ $\mathrm{CuSO}_{4}, 18 \mathrm{~h}$, thiobarbituric acid reactive substances $>0.50$ at $235 \mathrm{~nm}$ ), and $7.5 \mu \mathrm{g} / \mathrm{ml}$ of this preparation in carbonate-bicarbonate buffer, $\mathrm{pH}$ 9.0, was used to coat microtiter ELISA plates (Costar, Acton, MA, USA), and subsequently washed and blocked with $1 \%$ gelatin in $10 \mathrm{mM}$ phosphate-buffered saline (PBS), $\mathrm{pH}$ 7.2. Patient plasma samples were applied at a dilution of 1:400 in PBS $(\mathrm{v} / \mathrm{v})$ and allowed to react for $2 \mathrm{~h}$. Plates were washed 3 times with PBS-0.2\% Tween-20 (Fluka, New-Ulm, Germany) and again with PBS using an automated microtiter plate washer (Tecan, Crailsheim, Germany). A 
horseradish peroxidase-labeled immunopurified goat-anti human IgG (Dakopatts, Copenhagen, Denmark) at a dilution of 1:3,000 in PBS (v/v) was used to detect bound IgG antibodies. The reaction was developed using $0.1 \mathrm{mg} / \mathrm{ml}$ tetramethylbenzidine (Sigma, St. Louis, MO, USA) and $0.03 \% \mathrm{H}_{2} \mathrm{O}_{2}$ in 0.1 $\mathrm{M}$ citrate buffer, $\mathrm{pH}$ 5.5. The reaction was stopped by the addition of $2 \mathrm{~N} \mathrm{H}_{2} \mathrm{SO}_{4}$ (Merck, Darmstadt, Germany) and read using a microplate reader (Titre Tek, Franklin, MA USA) at $450 \mathrm{~nm}$. All tests were executed simultaneously in triplicate. Statistical analysis was carried out using ANOVA.

Analysis of the samples from HIV patients that could be considered to be immunocompromised showed that the lack or reduced numbers of $\mathrm{CD} 4^{+} \mathrm{T}$ cells $(<450$ cells/ $\mathrm{mm}^{3}$ ) had an impact on the production of antibodies resulting in lower anti-mLDL levels (Figure 1). Most interestingly, this incapacity to present an efficient immune response seems to last for a prolonged period of time (Ronchini KROM and Gidlund M, unpublished results). In experimental animal models using human cholesteryl ester transport protein transgenic mice or in models of experimentally induced atherosclerosis, we have recently shown that certain metabolic settings alter the profile of the anti-mLDL response and the presence of circulating mLDL (13). In addition, these findings were associated with the development of the extension of atherosclerotic lesions $(13,17)$. Lipodystrophy is a poorly defined clinical condition but involves both the anabolic and catabolic pathways of lipid synthesis $(18,19)$.

Our data show that lipodystrophy was correlated with a severe reduction in circulating anti-mLDL antibody levels (Figure 2) and most probably with an increase in $\mathrm{mLDL}$ level. However, the reduction in antibody levels in the lipodystrophy patients was not clearly related to low $\mathrm{CD}^{+}{ }^{+} \mathrm{T}$ cell counts $(\mathrm{P}=0.5)$, but this fact may have been due to the limited number of patients analyzed
(10 patients and 35 samples). In the light of the recent discussion about the appearance of secondary cardiovascular complications in HIV, especially after the introduction of HAART $(1,2)$, we consider the present data important.

On the basis of the concept that a functional immune system is important for preventing $\mathrm{CAD}$ by producing protective antibodies, our previous and present data indicate that the immune response against mLDL is an ongoing process and the lack of potentially protective antibodies may predispose to CAD. The prolonged immunodeficiency state seen in HIV may prevent this vital response. There is already evidence that cardiovascular complications occur in the presence of HAART (1). The study of a cohort of 96 HIV patients demonstrated (2) that there is a link between HAART and risk factors

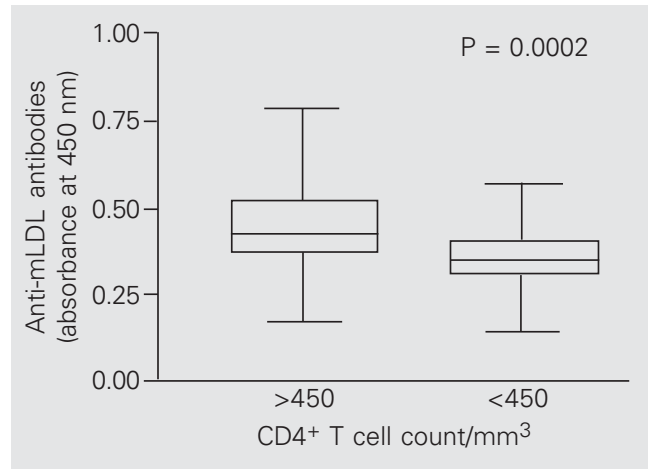

Figure 1. Reduced levels of circulating IgG antibodies against modified low density lipoprotein ( $\mathrm{mLDL}$ ) in patients with low $\mathrm{CD}^{+}{ }^{+} \mathrm{T}$ cell counts. Fifty-nine $\mathrm{HIV}$ + patients with normal $\mathrm{CD} 4^{+}$ cell counts ( $>450$ cells $/ \mathrm{mm}^{3}, \mathrm{~N}$ = 80 samples from 22 patients) or with reduced counts $\quad<450$ cells $/ \mathrm{mm}^{3}, \mathrm{~N}=110$ samples from 37 patients) were tested for the presence of plasma IgG antibodies against copper-oxized $\mathrm{LDL}\left(20 \mu \mathrm{M} \mathrm{CuSO}{ }_{4}, 18 \mathrm{~h}\right.$, thiobarbituric acid reactive substances $>0.50$ at $235 \mathrm{~nm}$ ) by ELISA (11-17). All assays were carried out simultaneously in triplicate. Statistical analysis was carried out using ANOVA.

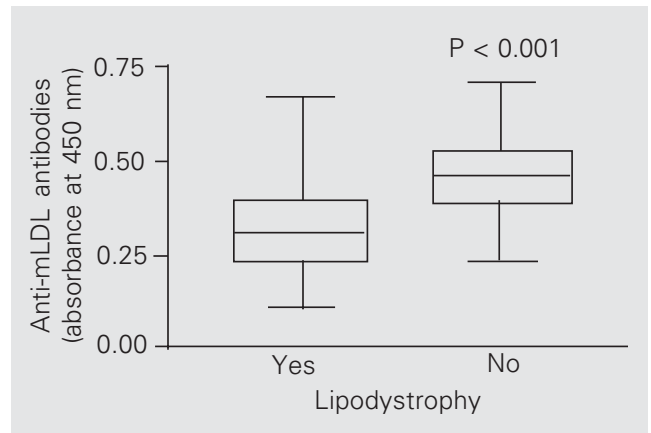

Figure 2. Low levels of circulating $\lg \mathrm{G}$ antibodies against modified low density lipoprotein $(\mathrm{mLDL})$ in patients with low $\mathrm{CD} 4{ }^{+} \mathrm{T}$ cell counts, in the presence or absence of lipodystrophy. Plasma samples from 22 HIV+ patients, 10 patients (number of samples tested $=35$ ) with confirmed lipodystrophy and 12 without lipodystrophy (number of samples tested $=42$ ) were assayed for the presence of $\operatorname{lgG}$ antibodies against copper-oxidized LDL $\left(20 \mu \mathrm{M} \mathrm{CuSO}_{4}, 18 \mathrm{~h}\right.$, thiobarbituric acid reactive substances $>0.50$ at $235 \mathrm{~nm}$ ) by ELISA. All assays were carried out simultaneously in triplicate. Statistical analysis was carried out using ANOVA. 
for CAD based on classical parameters, e.g., coronary artery calcification and the presence of atherogenic lipids and of $\mathrm{C}$ reactive protein. Even though we have not directly addressed this question our data indicate one more parameter that is strongly associated with CAD, i.e., the level of anti-mLDL antibodies. This may be important for further studies on the impact of the use of anti-HIV drugs which affect lipid metabolism in such a profound manner, also including immune parameters that may have secondary consequences. Taken together, these data emphasize the fact that more precise tools should be used to identify the various events leading to CAD. On this basis, further information about the participation of mLDL and antibodies against mLDL in HIV-associated CAD and lipodystrophy may not only provide a diagnostic tool but also new treatment strategies in the future.

\section{Acknowledgments}

We thank Drs. Marcia Carvalho, Luciana Uint and P. Boschcov for helpful suggestions, and Prof. Y.S. Bahkle for careful revision of the text.

\section{References}

1. Louie JK, Hsu LC, Osmond DH, Katz MH \& Schwarcz SK (2002). Trends in causes of death among persons with acquired immunodeficiency syndrome in the era of highly active antiretroviral therapy, San Francisco, 1994-1998. Journal of Infectious Diseases, 186: 1023-1027.

2. Meng Q, Lima JA, Lai H et al. (2002). Coronary artery calcification, atherogenic lipid changes, and increased erythrocyte volume in black injection drug users infected with human immunodeficiency virus-1 treated with protease inhibitors. American Heart Journal, 144: $642-648$

3. Esterbauer H, Gebicki J, Puhl H \& Jurgens G (1992). The role of lipid peroxidation and antioxidants in oxidative modification of LDL. Free Radical Biology and Medicine, 13: 341-390.

4. Hevonoja T, Pentikainen MO, Hyvonen MT, Kovanen PT \& AlaKorpela M (2000). Structure of low density lipoprotein (LDL) particles: basis for understanding molecular changes in modified LDL. Biochimica et Biophysica Acta, 1488: 189-210.

5. Frostegard J, Nilsson J, Haegerstrand A, Hamsten A, Wigzell H \& Gidlund M (1990). Oxidized low density lipoprotein induces differentiation and adhesion of human monocytes and the monocytic cell line U937. Proceedings of the National Academy of Sciences, USA, 87: 904-908

6. Witztum JL \& Steinberg D (2001). The oxidative modification hypothesis of atherosclerosis: does it hold for humans? Trends in Cardiovascular Medicine, 11: 93-102.

7. Hansson GK (2002). Vaccination against atherosclerosis: science or fiction? Circulation, 106: 1599-1601.

8. Shoenfeld $Y$, Sherer $Y$ \& Harats $D$ (2001). Artherosclerosis as an infectious, inflammatory and autoimmune disease. Trends in Immunology, 22: 293-295.

9. Svensjo E, Boschcov P, Ketelhuth DF, Jancar S \& Gidlund M (2003). Increased microvascular permeability in the hamster cheek pouch induced by oxidized low density lipoprotein (oxLDL) and some fragmented apolipoprotein B proteins. Inflammation Research, 52: 215220.

10. Carvalho MD, Harada LM, Gidlund M, Ketelhuth DF, Boschcov P \& Quintão EC (2002). Macrophages take up triacylglycerol-rich emul- sions at a faster rate upon co-incubation with native and modified LDL: An investigation on the role of natural chylomicrons in atherosclerosis. Journal of Cellular Biochemistry, 84: 309-323.

11. Zaratin A, Gidlund M, Boschcov P, Castilho L \& de Faria EC (2002). Antibodies against oxidized low-density lipoprotein in normolipidemic smokers. American Journal of Cardiology, 90: 651-653.

12. Uint L, Gebara OCE, Pinto LB, Wajngarten M, Boschcov $P$, da Luz PL \& Gidlund M (2003). Hormone replacement therapy increases levels of antibodies against heat shock protein 65 and certain species of oxidized low density lipoprotein. Brazilian Journal of Medical and Biological Research, 36: 491-494.

13. Cazita PM, Berti JA, Aoki C, Gidlund M, Harada LM, Nunes VS, Quintao EC \& Oliveira HC (2003). Cholesteryl ester transfer protein expression attenuates atherosclerosis in ovariectomized mice. Journal of Lipid Research, 44: 33-40.

14. Wu R, de Faire U, Lemne C, Witztum JL \& Frostegard J (1999). Autoantibodies to OxLDL are decreased in individuals with borderline hypertension. Hypertension, 33: 53-59.

15. Shoenfeld Y, Harats D \& George J (2000). Heat shock protein $60 / 65$, beta 2-glycoprotein I and oxidized LDL as players in murine atherosclerosis. Journal of Autoimmunity, 15: 199-202.

16. Shoji T, Nishizawa $Y$, Fukumoto $M$, Shimamura $K$, Kimura J, Kanda H, Emoto M, Kawagishi T \& Morii H (2000). Inverse relationship between circulating oxidized low density lipoprotein (oxLDL) and anti-oxLDL antibody levels in healthy subjects. Atherosclerosis, 148: 171-177.

17. Damasceno NR, Goto H, Rodrigues FM, Dias CT, Okawabata FS, Abdalla DS \& Gidlund M (2000). Soy protein isolate reduces the oxidizability of LDL and the generation of oxidized LDL autoantibodies in rabbits with diet-induced atherosclerosis. Journal of Nutrition, 130: 2641-2647.

18. Carr A (2000). HIV protease inhibitor-related lipodystrophy syndrome. Clinical Infectious Diseases, 30 (Suppl II): 135-142.

19. Christeff N, Melchior JC, Truchis P, Perrone C, Nunez EA \& Gougeon $M-L$ (1999). Correlation between increased cortisol:DHEA ratio and malnutrition in HIV-positive men. Nutrition, 15: 534-539. 